\section{Studia z Filologii Polskiej i Słowiańskiej}

DOI: $10.11649 /$ sfps.2000
Studia z Filologii Polskiej i Słowiańskiej, 55

Warszawa 2020

Article No. 2000

Citation:

Зелинская, О. Ю. (2020). Предостережения и запреты как способ воздействия на адресата в украинских проповедях XVII-XVIII вв. Studia z Filologii Polskiej i Słowiańskiej, 55, Article 2000. https://doi.org/10.11649/sfps.2000

Zelinskaia, O. I. (2020). Predosterezheniia i zaprety kak sposob vozdeǐstviia na adresata v ukrainskikh propovediakh XVIIXVIII vv. Studia z Filologii Polskiej i Stowiańskiej, 55, Article 2000. https://doi.org/10.11649/sfps.2000

\author{
Оксана Юрьевна 3 елинская \\ (Уманский государственный педагогический \\ университет имени Павла Тычины)
}

\title{
Предостережения и запреты как способ воздействия на адресата в украинских проповедях XVII-XVIII вв.
}

Психологическое воздействие на человека, в результате которого должны измениться его субъективные характеристики (ценностные ориентации, деятельность, поведение), как отмечают ученые, являются важной стороной человеческого бытия (Балл \& Бургин, 1994, с. 56; Ковалев, 1987, с. 41).

Субъект, произносящий высказывание, совершает речевой акт - действие, реализующее актуальную интенцию и направленное на адресата. Разновидностью психологического воздействия есть акт речевого общения, во время которого субъект воздействия стремится спровоцировать поведение реципиента в нужном направлении (Леонтьев, 1997, сс. 271, 273). А. Кинцель, оценивая значимость речевого воздействия, отмечает, что формирование человека как социального существа происходит, прежде всего, за счет речевого воздействия (Кинцель, 2013, с. 151). В религиозной

This is an Open Access article distributed under the terms of the Creative Commons Attribution 3.0 PL License (creativecommons.org/licenses/by/3.0/pl/), which permits redistribution, commercial and non-commercial, provided that the article is properly cited. (c) The Author(s) 2020.

Publisher: Institute of Slavic Studies, Polish Academy of Sciences

[Wydawca: Instytut Slawistyki Polskiej Akademii Nauk] 
коммуникации такое воздействие направлено на приобщение к христианским нормам и ценностям. Коррекция поведения человека входит в круг задач священника, которые наиболее успешно он осуществляет в своей проповеднической деятельности.

Важнейшая коммуникативная цель адресанта (проповедника) путем словесного влияния укреплять прихожан в вере, склонять их строить свою жизнь согласно Заповедям Божьим, а также предостеречь их от совершения поступков и действий, противоречащих Заповедям. Весь спектр поступков, явлений, действий и даже мыслей, нарушающих христианские принципы, воплощает понятие «грех». Для реализации намерения предотвратить греховное поведение, убедить каждого не совершать греховных поступков и действий проповедник в качестве средства психологического воздействия использует речевые акты предостережения и запрета. Большинство лингвистов прагматическую функцию этих речевых актов изучали на материале современных текстов.

Цель этой статьи - исследовать традицию использования речевых актов предостережения и запрета в диахронии, раскрыть специфику их употребления как средства воздействия на адресатов в проповедническом дискурсе.

Материалом исследования избраны памятники письменности украинского языка - христианские проповеди XVII-XVIII вв.: традиционные, изданные в сборниках, именуемых Учительными евангелиями, и проповеди нового типа, барочные, сформировавшиеся под влиянием европейской эстетики эпохи Барокко, авторства наиболее известных украинских проповедников И. Галятовского, А. Радивиловского․․

В основе всех жанров религиозного дискурса лежит феномен веры, которая в аспекте психологических исследований рассматривается как отображение

1 Многие исследователи утверждают, что барочные проповеди сформировались в украинской культуре под влиянием польской, поэтому их в научной литературе часто называют латино-польскими. Особое влияние на развитие украинского проповедничества эпохи Барокко оказали книги польских проповедников Ф. Дзеловского Gościniec prosty do nieba ... (Краков, 1677) и Ф. Млодзяновского Kazanie i homilyie na niedziele doroczne (Познань, 1681). Частично вопрос о польском влиянии на украинскую барочную проповедь изложен в статье Барочная проповедь как отражение украинско-польских связей (Зелінська, 2013). Влияние польских проповедников на специфику выбора средств речевого воздействия на адресата в произведениях украинских проповедников требует специального исследования, что есть перспективой для дальнейших студий. 
базовых потребностей человека в безопасности, любви и признании (Савелюк, 2015, с. 81). В лингвистической литературе высказывания, передающие коммуникативное значение запрета и предупреждения, чаще всего именуют превентивами и прохибитивами. В работах встречаем также термин авертив (от фр. avertir - 'предупреждать') (Ерофеева, 2015, с. 164). Анализируя высказывания авертивной семантики на материале французского языка, Е. Ерофеева отмечает сходство в плане выражения речевого акта предупреждения с речевым актом угрозы и рассматривает их в качестве гипонимов по отношению к более широкой группе высказываний с иллокутивным значением «предупреждение нежелательного действия» (Ерофеева, 2014, с. 240).

Речевые акты предостережения и запрета неоднократно становились предметом изучения лингвистов на материале современных языков. Н. Добрушина изучала грамматические формы и конструкции со значением опасения и предостережения в разных языках. Автор акцентирует, что фокусом превентива является предотвращение нежелательного события; побуждение адресата не совершать действия. Превентивные конструкции могут призывать либо к неосуществлению события, либо к неосуществлению действия, которое может стать причиной осуществления события (Добрушина, 2006, сс. 30, 51).

Семантику и способы выражения превентива в русском языке изучала Ю. Кленина. Автор обращает внимание, что предостережение традиционно рассматривали как особое значение отрицательной императивной формы глагола совершенного вида, т. е. как явление морфологического уровня (Кленина, 2003, с. 59). На этом акцентировала и Н. Добрушина, указывая, что поскольку основной целью превентива является побуждение адресата не совершать действия, то превентивные конструкции в описаниях, как правило, рассматривались среди разновидностей императивных форм (Добрушина, 2006, с. 51). В результате наблюдений за особенностями функционирования превентива Ю. Кленина пришла к выводу, что превентив - это особый коммуникативно-прагматический тип волеизъявительного высказывания, реализующий семантику предостережения, он функционально шире глагольной словоформы, а семантика предостережения представляет собой систему разноуровневых средств: лексических, морфологических, синтаксических, ритмико-интонационных (Кленина, 2003, с. 38). Близки по значению к превентивам прохибитивы - речевые акты запрета. Например, Ф. Назари, рассматривая способы выражения запрета в русском языке, использует 
термин запрет-превентив, которым обозначает волеизъявление адресанта, относящееся к сфере будущего, когда действие адресатом еще не совершенное, но может быть осуществлено им (Назари, 2011, с. 684).

Н. Куравская, обобщая выводы многих лингвистов о природе прохибитива, определяет его как категорическое волеизъявление говорящего, направленное на предотвращение действия или прекращение уже начатого (Куравська, 2016, сс. 70, 73). Таким образом, интенция в обоих типах высказываний - превентива и прохибитива - направлена на недопущение совершения какого-либо действия или поступка.

Одним из главных языковых средств выражения волеизъявления проповедника, направленного на предотвращение выполнения действия или поступка, становятся лексемы с общим значением 'предостерегать'. Ю. Кленина, выделяя этот тип, называет его лексически эксплицированным предостережением, когда превентивная семантика содержится в самой лексеме глаголов со значением боязни и опасения (Кленина, 2003, с. 118).

В исследуемых текстах украинских проповедей XVII-XVIII вв. эту роль выполняли глаголы хронитися, стерегтися, вистертгатися, запобюгти. Обращаясь к адресатам, священник употребляет их в разных глагольных формах:

первого лица множественного числа:

Стережпмшса претш, Братїе [...] Не чинпмм того, абысмш завыдячи богатшимъ в дарахъ, и себе внгвечъ оборочали, и дрүгимъ до погибели причиною были (Євангеліє учителное, 1637, с. 182);

Хронпмо жъ ск мы грпхшвъ, поневажъ за грпхи бгъ хоробами людей навъжаєт(б) (Галятовський, 1659/1985, с. 101);

Выстертгаймосм гргховъ и для того, бо за гргхи смертю бг̈ъ людей караєть (Галятовський, 1659/1985, с. 102);

второго лица множественного числа изъявительного наклонения:

Стережптес м тоєи спти пекелнои (Галятовський, 1659/1985, с. 69);

[...] толк (Семя слова Божія, 1772, с. 17);

инфинитива:

Тыхт геретикшвъ невпрныхт маємо хронитиса, не вприти тому, за щьо шни мовжтъ и не слухати науки ихъ (Галятовський, 1659/1985, с. 78). 
Близкими по значению к выше названным глаголам в ситуации предостережения были вербаты боятися, убоятися:

[...] абысмо всякагш гргхха не толкш выстерпгалися, но и боялися наветь (Семя слова Божія, 1772, с. 18);

Покижъ такъ бүдемъ зъ Бг̈омъ жартовати? [...] можемо Бг̈а на впки


слова Божія, 1772, с. 38).

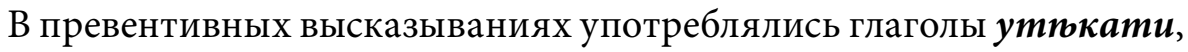
сторонитися, обозначающие действия, направленные на создание воображаемой дистанции между личностью и греховными чувствами, мыслями, поступками, напр.:

[...] оутпкаймо wैхтивости и пожадливости богатствъ (Евангеліе учителное, 1616, с. 505);

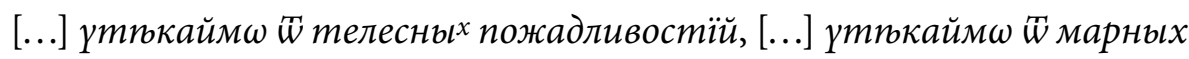
сегшсвптных роскошій (Євангеліє учителное, 1637, с. 365);

Оутпкаймш [...] $\ddot{w}$ справ незбожных (Євангеліє учителное, 1637, с. 414); Сторонпмшса роскоханя в сегшсвптных роскошных марностах (Євангеліє учителное, 1637, с. 414).

Для передачи коммуникативного смысла предупреждения и апелляции к сознанию адресатов проповедник употреблял глаголы знать, ведать:

Роскоши сегш облүднаго свпта [...] сүть то перепелици жидовскїи [...] Знайте, же гробомъ пахнуть, єсли ктш до нихъ рүить свои лакоме простретъ (Радивиловський, 1676, с. 60);

Кто добра свои шборочаєть на марнотравства, на пїжтики, на строй вытворный, на мүзики, впдайте [...] таковый оекш самб,

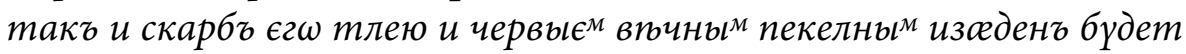
(Радивиловський, 1676, с. 348).

В приведенных контекстах о нежелательном действии говорится как о таком, которое уже произошло или просходит, а авертивная семантика содержится в описываемых негативных последствиях.

В высказываниях с превентивной семантикой роль речевых маркеров предупреждения выполняли слова и словосочетания, обозначающие процессы мыслительной деятельности - напоминаю, мпймо в памАти: 
Православныи хр(с)тїнне! [...] Мпймо в(б) памяти своєй свпчу запаленую, огнь вичный пекелный, который грпшнымъ людемъ єст(ъ) наготованый (Галятовський, 1659/1985, с. 121);

И $\omega$ томъ ое ныни напоминаю васъ, да бысмо, показавщи оусерднүю ко Хргітү любовь, потомг не шбернүлиса на негожв ненавистїю: да бысмо, приндвши его до дүши своей миль, не выганяли зновү гртьхомб (Семя слова Божія, 1772, с. 158).

Способом имплицитного выражения предостережений было раскрытие греховной сущности явления, по форме сходного с дефиницией и содержащее негативную оценку, напр.:

Ллобствовати и сритися на кого ли бүдь, єсть дюло ш себе sловредное, бгомерзкое, и самогш дїавола (Семя слова Божія, 1772, с. 127).

Такие определения подразумевали необходимость избежания названных действий и поступков. Подтверждением превентивной функции подобных дефиниций служат примеры, когда они предшествуют превентиву или употреблены после него:

[...] кождый грпхъ забойцею єсть и згүбиею дйи. Выстерпгаймосм братїє дүшевного крви плынен

Всею дүшею $\ddot{w}$ драппнства, и $\ddot{w}$ лихвы оутпкаймо [...] Лихва есть рожай ждовитого гадү (Євангеліє учителное, 1637, сс. 589-590).

По нашим наблюдениям, наиболее активным средством передачи предостережения и запрета в проповедях становятся глаголы в форме отрицательного императива, обозначающие нежелательное действие. Д. Звездин отмечает, что многочисленные императивные формы выражают одну из важнейших коммуникативных задач проповеди - нравственный призыв (Звездин, 2011, с. 54). В аспекте этого исследования интересны рассуждения ученого-философа М. Гельфонда, который, изучая этическую сущность морали, приходит к выводу, что «мораль только тогда есть мораль, когда она всецело бескорыстна, автономна и безусловно императивна, что находит свое наиболее адекватное выражение в „негативной“ форме - в форме абсолютных моральных запретов, обеспечивающих человеку нормативную возможность всецело руководствоваться предписаниями практического разума как доброй воли», в сознательном отказе субъекта от совершения действия, на которое наложен категорический моральный запрет (Гельфонд, 2014, сc. 27, 30). 
В исследуемых проповедях предостережения и запреты направлены как на конкретные обыденные ситуации, так и на моральные жизненные установки в целом. Наиболее универсальным было предостережение к совершению греха: Толкш не грпшиьз (Семя слова Божія, 1772, с. 17). Многие предостережения и запреты, выраженные отрицательной формой императива, основаны на Декалоге - десяти Божьих старозаветных заповедях, которые были дополнены и усовершенствованны Иисусом Христом. В заповедях, как отметила А. Паславская, пересекаются речевые акты приказа, запрета, наставления, предостережения (Паславська, 2010, с. 63).

В проповеднических произведениях наблюдаем разные способы введения в текст евангельских запретов. Автор мог использовать перечень запретов, ссылаясь на слова Иисуса, напр.:

А Ійс рекль: Не бүдешъ забывати. Не бүдешь чүжоложити. Не бүдешь красти. Не бүдешь мовити фалшивого свпдоиства (Євангеліє учителное, 1637, с. 496),

мог включать перечень в собственный монолог, без отсылки к Священному Писанию, напр.:


не забывайм поглддайм учителное, 1637, с. 503),

а также акцентировать на любой из заповедей:

Не давай фалшивого свюдоиства на ближнего твоего (Євангеліє учителное, 1637, с. 290).

Отрицательными императивами проповедник обозначал множество других действий, от исполнения которых предостерегал адресатов:

Чүжого не лүппжмо (Евангеліе учителное, 1616, с. 506);

Милүймо братїє оубогихъ, не перезираймо оукрывженыхъ, чүжого дшбра не драпюжмо, не кривдмо нпкого, слшвъ порожних не прїимүймо (Евангеліе учителное, 1616, с. 931);

[...] до повсевременныхъ пюсній и молитвъ люнивими не бүдмш (Євангеліє учителное, 1637, с. 105); 
Не шукайте ни живота, ани радости в роскошах сего свпта, в обжирствах, пннствах и иных гртьхах смертельних (Радивиловський, 1676, с. 60); [...] не похвал йммо себе такъ, скъ Фарїсей (Семя слова Божія, 1772, с. 57).

Проповедник осознавал то, что верующие, к которым он обращается с проповедью, уже могли совершить нежелательный поступок или действие. Чтобы не оттолкнуть согрешивших и не допустить возникновения чувства отчаяния, автор избегает порицаний и призывает приостановить пребывание в состоянии греха. Исследуемые тексты фиксируют наличие речевых актов, направленных на предотвращение дальнейшего совершения греховных поступков. В этих случаях интенцию автора вербализировали словосочетание больше не чинити, больше чинити выстернгалися, глаголы перестати, оставити, занехаять:

До того єсли сл в(ъ) грпьхахъ якихъ знайдуємо, жалуймо за нихъ [...] и перестаньмо грпиити (Галятовський, 1659/1985, с. 139);

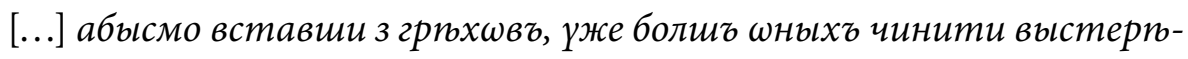
галися, слүхачү православный (Радивиловський, 1688, с. 85);

Жалуй, обтщай пред Бг̃ом тое больше не чинити, не говорити, не мислити (Семя слова Божія, 1772, с. 43);

Хощемг оубо Бг̈ү и людем показати, щьо ш̈ самой смерти на дүшп оуже волнїи есмьт? Фставможъ, занехаймо и признакшвъ тоя: то есть жартшвъ, слшвъ нечистыхъ, лядаякихъ, лання и тамъ далпй (Семя слова Божія, 1772, с. 173);

[...] перестанмо Ггда Бг̃а хүлити (Семя слова Божія, 1772, с. 347).

Задуматься над прекращением безнравственных поступков автор рекомендует и самим верующим. В приведенном далее контексте семантику предостережения передают глаголы прервати, перешкодити:

Слүчится тебп, же кто шбмовляеть ближняго [...] перешкодь томү

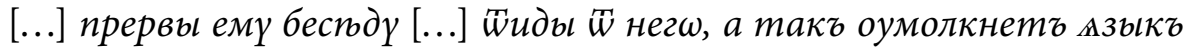
sлортчивый (Семя слова Божія, 1772, с. 368).

Для проповеднического дискурса примечательно усложнение превентивных высказываний менасивом - речевым актом угрозы. Е. Ерофеева отмечает, что практически любой речевой акт, выражающий побудительную интенцию говорящего, может в определенном контексте стать угрозой, если к нему при- 
соединяется речевой акт обещания негативных последствий (Ерофеева, 2014, c. 244). Н. Войцеховская считает, что менасив как средство коммуникативного влияния направлен на изменение деятельности адресата путем апелляции к чувству страха и опасения и, как правило, оказывает давление на собеседника и игнорирует его интересы (Войцехівська, 2014, с. 19). Специфическим для рассматриваемых нами контекстов, принадлежащих к сфере религиозной коммуникации, есть то, что угроза исходит не от говорящего, а от третьего участника коммуникации. Адресат только предупреждает об этой угрозе, пытаясь таким образом предотвратить поступки и действия, влекущие тяжкие последствия. Убеждая прихожан не совершать греховных поступков, священник напоминал о неминуемом наказании, Божьей каре, которой они будут подвергнуты за содеянное. Согласно с христианской религией, наиболее страшным наказанием за совершенные греховные поступки было отправление человека в ад, который в украинском языке назывался словом пекло:

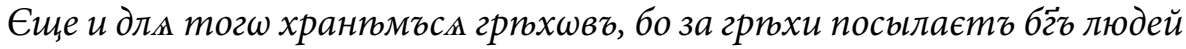
до пекла на впьныи муки (Галятовський, 1659/1985, с. 102).

Проповедник предупреждал, что Божья кара может постичь человека и в земной жизни в виде болезней, эпидемий, войны и проч.:

Выстерпгаймоса грпховъ и для тогш, бо за гриххи караєть бг̈ъ людей голодомъ. [...] За грпххи караєтъ бг̈ъ войною, неволею, спустошен(ь) емъ и упадкомъ кролевства, панства и землть розмаитыи (Галятовський, 1659/1985, с. 102).

Предостерегая от нежелательных поступков или запрещая их, проповедник побуждал адресатов к выбору иной модели поведения, указывая, как должен поступать настоящий христианин. Превентивные высказывания дополнялись рекомендациями и наставлениями. На синтаксическом уровне такие речевые акты воплощались в предложения с семантикой противопоставления с использованием противительных союзов $\boldsymbol{a}, \boldsymbol{a л e}$ или без них:

До того удалмймося $\omega(m)$ свпта, не уганяймося за богатствами и иншыми марностмми свпцкими, але служпмо бгу (Галятовський, 1659/1985, с. 73);

И мы жъ товарыства з(б) людми злыми не мпймо, але з(б) добрыми людми конверсуймо, то волными $\omega(m)$ гргхха зостанемо [...] (Галятовський, 1659/1985, с. 150); 


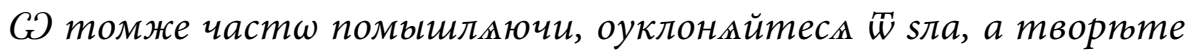
біггое, таковымъ бо способомъ избюжите вючныхъ мүкъ, а полүчите радость (Семя слова Божія, 1772, с. 83);

[...] боймося грпиити, творимъ же дшбрая (Семя слова Божія, 1772, с. 357).

В системе средств убеждения, направленных на недопущение совершения греховного действия, выделяем апелляцию к прецедентным феноменам. Авторы использовали различные примеры, небольшие рассказы поучительного содержания. В традиционных проповедях источником поучительных примеров были старозаветные и евангельские истории. Авторы барочных проповедей использовали и много иного материала. Включая в проповедь поучительный пример с негативным исходом, проповедник предупреждал адресатов о возможной опасности, если нежелательное действие будет ими выполнено. Сформулированный вывод после прослушанного примера включал высказывания превентивной семантики:


компанюи стерегли, абы $\vec{c}_{\mathcal{M}}$ з нею жаднои не мпли сполечности, если хочемг оуйти гргххвъ (Радивиловський, 1688, с. 675);

Слүхачү православный. Видячи мы такъ нещасливый житїя конець лакомогш богача [...] Стережпмса такомства жкк згүбы, сккш добродителей искоренителки, а грпххе ${ }^{\overrightarrow{8}}$ оумншжителки (Радивиловський, 1688$, c. 717$)$.

Таким образом, предостережение логически вытекало из приведенных примеров.

Использование специальных речевых маркеров видяии, видюте сами, приклады и доводь могут нас побудити, обращенных к базовой модальности реципиента, создавало эффект, что адресаты самостоятельно пришли к такому выводу, напр.:

И такъ оуже къ вамъ шбрнщаю мою рпчь [...] Видюте самы теперь, гкъ великоє sло єсть зависть. Фкинможъ түю и жкимб можемо способомъ шжентьл ш

[...] тіи, що сказалиса приклады и доводы могүть насъ побүдити, да не прїемлемъ до срияа, но да гнүшаемся такъ мерзостнагш Бгेү, и людямб самовреднагш пристрастїя (Семя слова Божія, 1772, сс. 132-133). 
Авторитетность и убедительность предостережений усиливается, когда они являются цитатами из Священного Писания. В приведенных далее примерах автор цитирует Сираха, называя его небесным любомудром, слова Иисуса Христа из Евангелия, пророка Захарии:

Послүхаймо братїє Пророка Б̈ного Захарїи о томъ мовмчого, а насъ напоминаючого: злости брата своего, мовитъ, нпхто на памжти срдиа нехай не носить, и злопомнпнїа на ближныхъ своих нпхто на памхти мыстій своихъ нехай не держитъ (Евангеліе учителное, 1616, с. 76);

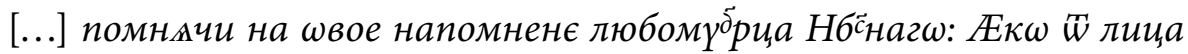
sмїина, бгжи щ̈ гргхха (Радивиловський, 1688, с. 646);


ловський, 1688, с. 717$)$.

Во многих случаях замечаем, что священник пытается высказывать предостережения ненавязчиво, он явно демонстрирует желание, чтобы адресаты сами добровольно избрали жизненные стратегии. В таких случаях предостережения становятся рекомендациями, которые адресат может принять согласно своей воле. Намерение оставить выбор за адресатом автор выражает речевыми маркерами, в структуру которых входят лексические единицы со значением 'желать, хотеть': если истинно желаемь, если хочемь, да ежели хощемь, ще ли хотпте:

Овожв если хочемо погордит славою мира сегш и гргхов ся оустеречи, шборочаймо мысль нашү күнбү, мыслмо ш славп впчной, а не ш дочасной (Радивиловський, 1676, с. 310);

Аще ти боитесл, и хощете тогш лла избюжати, то часть помышлмйте, що вамъ конечне потреба бүдеть стати пред Хрстомг страшнымъ судїею (Семя слова Божія, 1772, с. 83);

Если истиннш желаемь [...], то потреба намъ шставити той пүть, которымъ даже до нынюь ходили есмьи, тоесть пүть грпховній, а ити тымъ пүтемъ, которымъ всегда ходиль, и ходити наүчаль Гсдь нашь Ійсъ Хрстоов (Семя слова Божія, 1772, с. 255).

Обратим внимание на то, что проповедник прибегал к разным способам создания эмоционального фона, способствующего принятию реципиентом авторской концепции ценностей. Среди них номинация адресатов словом брат, что нивелировало позицию превосходства проповедника: 
Оксана Юрьевна Зелинская Предостережения и запреты как способ воздействия...

Үбоймося прето братїє мои, а слишачи о такъ страчномъ и срокгомъ судь и о такъ окрүтныхъ муках, стра $\vec{u}_{\mathcal{M о с я ~}}$ и плачмо (Евангеліе учителное, 1616, с. 56).

Создание атмосферы равенства достигалось использованием глаголов в грамматических формах первого лица множественного числа:

Понехаймо вшелнкихъ злыхъ обычаевъ, облуды, подстүпства, и зрады (Евангеліе учителное, 1616, с. 99).

С помощью местоимения $\boldsymbol{м \boldsymbol { b }}$ проповедник достигал эффекта тесного единения с прихожанами:

И мы прето братїе всесильного своего створителя и Бг̃а не ображаймо, не гнпвпмо, бжсвенныхъ его приказанйй не занедбываймо, а на кождый день и годинү просити его не занехиваймо (Евангеліе учителное, 1616, с. 277).

Искренность переживаний автора за прихожан передавали перформативы просить, молить, предшествующие превентиву:

Прошу прето васъ, Братїє, [...] не нарпкаймш на Бг̃а, анпся емү оуприкраймш (Євангеліє учителное, 1637, с. 133);

Не ослабпваймш прето прошү ва $\vec{c}$, и не опүскаймшск, анп поддавай-

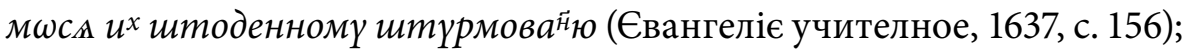
[...] молю васъ слүшателїє, окоже и себе самого оувпщаваю, да на зависть дрүгихъ [...] не смотримъ (Семя слова Божія, 1772, с. 115).

Большей силой убеждения обладали превентивы-заклинания:

Чи маємо жъ вонтпити $\omega$ своємъ збавеню, же не мншго людей будет(ъ) в нбъr? Не дай того, бъне, абы смо вонтпити мпли (Галятовський, $1659 / 1985$, c. 138).

Для убеждения и приобщения прихожан к нужной модели поведения автор использует различные выразительные средства в структуре авертивов. Формированию убеждения не совершать того или иного греховного действия способствуют эпитеты, выражающие негативную оценку, например, грех злопамятства проповедник называет душегубным:

Оутькаймо прето братїє ш̈ дүшегүбной сей заразы злопомнюнӥн (Евангеліе учителное, 1616, с. 77), 
а обращаясь к людям, поклоняющимся богатству, как богу, употребляет эпитет мерзенный:

[...] обрыдмо собп того бога, [...] мерзенного того бога понехаймо (Евангеліе учителное, 1616, с. 85).

Для усиления эффективности речевого воздействия авторы проповедей часто прибегают к различным риторическим фигурам:

амплификации:

Имы прето братіе всесильного своего створителн и Бга не ображаймо, не гнпввьмо, бжссвенныхъ его приказаній не занедбываймо, а на кождый день и годинү просити его не занехиваймо (Евангеліе учителное, 1616, с. 277); градации:

[...] припоминаймо собп бг̈а, встьдаймоса и боймося пре (д) бӟскими очима грпхт чинити, жебы смш грпхшмғ своимъ бга не шбразили (Галятовський, 1659/1985, с. 150);

парной синонимии:

Не зайзрпмм зльмъ людемъ, анп завыдмш тым котрыю [...] незбожности полнать (Євангеліє учителное, 1637, с. 105);

Люнивствомъ себе не грүзюмш и не топюмш (Євангеліє учителное, 1637, c. 464).

Эти риторические фигуры создавали эмоциональную речь, «эмоциональный нажим на аудиторию», что, как утверждает И. Стернин, оказывается более действенным, нежели логическая аргументация (Стернин, 2015, с. 265).

\section{Выводы}

Использование в проповедническом дискурсе речевых актов предостережения и запрета обусловлено интенцией автора предостеречь адресатов от поступков, противоречащих христианским нормам. Исследуемые тексты свидетельствуют, что для воплощения семантики предостережения проповедники используют различные лексические и грамматические средства, а для большего убеждения и приобщения прихожан к нужной 
модели поведения - различные выразительные средства в структуре превентивов. Высказывая предостережения, проповедник стремился создать атмосферу доверия и равенства. Исследуемый материал дает основания сделать выводы о мощном потенциале языкового ресурса украинского языка XVII-XVIII вв. для обеспечения речевого воздействия и открывает перспективы для изучения динамики его дальнейшего развития.

\section{Библиография}

Балл, Г., \& Бургин, М. (1994). Анализ психологических воздействий и его педагогическое значение. Вопросы психологии, 1994(4), 56-66.

Войцехівська, Н. (2014). Засоби вираження погрози в українському конфліктному діалогічному дискурсі. Гуманітарна освіта в технічних вищих навчальних закладах, 2014(30), 17-30.

Галятовський, I. (1985). Ключ розумъння. In I. Галятовський, Ключ розуміння (pp. 53-211). Наукова думка. (Original work published 1659).

Гельфонд, М. (2014). К вопросу о соотношении морали и цивилизации. Этическая мыслль, 14, 25-35.

Добрушина, Н. (2006). Грамматические формы и конструкции со значением опасения и предостережения. Вопросы языкознания, 2006(2), 28-67.

Евангеліе учителное, албо казаня на кождую неделю и свята урочистыи. (1616). Друкарня Вільнюського братства. http://irbis-nbuv.gov.ua/dlib/item/0000067

Ерофеева, Е. (2014). Речевые акты угрозы и предупреждения и их косвенная реализация во французском дискурсе. Политическая лингвистика, 2014(4), 240-247.

Ерофеева, Е. (2015). Роль социального статуса коммуникантов в выражении менасивной и авертивной семантики (на примере французского дискурса). Политическая лингвистика, 2015(1), 164-168.

Євангеліє учителное, албо казаня на кождую неділю и свята урочистыі. (1637). Друкарня Києво-Печерської лаври. http://irbis-nbuv.gov.ua/dlib/item/0000059

Звездин, Д. (2011). Православная проповедь как коммуникативный акт (на примере творчества архимандрита Иоанна Крестьянкина). Вестник Челябинского государственного университета, 2011(33): Филология; Искусствоведение, 60, 52-54.

Зелінська, О. Ю. (2013). Барокова проповідь як відображення українсько-польських зв’язків. In R. Dymczyk, I. Krywoszeja, \& N. Morawiec (Eds.), Polsko-ukraiński dyskurs humanistyczny (pp. 275-281). Wydawnictwo "Taurus".

Кинцель, А. (2013). Психолингвистические механизмы речевого воздействия. Известия Алтайского государственного университета, 2(2), 150-154. https://doi.org/10.14258 /izvasu(2013)2.2-33 
Кленина, Ю. (2003). Превентив: Семантика и способы выражения [Unpublished doctoral dissertation]. Рязанский государственный университет имени С. А. Есенина.

Ковалев, Г. (1987). Три парадигмы в психологии - три стратегии психологического воздействия. Вопросы психологии, 1987(3), 41-49.

Куравська, Н. (2016). Семантика прохібітива та засоби його вираження в сучасній українській мові. Актуальні проблеми філології та перекладознавства, 10(2), 70-74.

Леонтьев, А. (1997). Психология общения. Смысл.

Мечковская, Н. Б. (1998). Язык и религия. Агентство “ФАИР”.

Назари, Ф. (2011). Способы выражения запрета в русском языке. Вестник Нижегородского университета им. Н. И. Лобачевского, 2011(6), 684-686.

Паславська, А. (2010). Мовленнєвий жанр “заповідь” в аспекті міжкультурної комунікаціiі. In Р. Помірко, Ф. Бацевич, \& А. Паславська, Мовленнєві жанри в міжкультурній комунікаціі (рp. 63-82). ПАіС.

Радивиловський, А. (1676). Огородок Маріи Богородицьь. Друкарня Києво-Печерської лаври. http://irbis-nbuv.gov.ua/dlib/item/0000123

Радивиловський, А. (1688). Венеи, Христов. Друкарня Києво-Печерської лаври. http:// irbis-nbuv.gov.ua/dlib/item/0000071

Савелюк, Н. (2015). Психологические особенности основных жанров религиозного дискурса: молитвы, исповеди, проповеди и обрядового действия. Science and Education: A New Dimension: Pedagogy and Psychology, 3(30/59), 78-81.

Семя слова Божія. (1772). Друкарня Успенського монастиря. http://irbis-nbuv.gov.ua/dlib /item/0000015

Стернин, И. (2015). Основы речевого воздействия. Директ Медиа.

\section{Bibliography (Transliteration)}

Ball, G., \& Burgin, M. (1994). Analiz psikhologicheskikh vozdeǐstviı̌ i ego pedagogicheskoe znachenie. Voprosy psikhologii, 1994(4), 56-66.

Dobrushina, N. (2006). Grammaticheskie formy i konstruktsii so znacheniem opaseniia i predosterezheniia. Voprosy iazykoznaniia, 2006(2), 28-67.

Erofeeva, E. (2014). Rechevye akty ugrozy i preduprezhdeniia i ikh kosvennaia realizatsiia vo frantsuzskom diskurse. Politicheskaia lingvistika, 2014(4), 240-247.

Erofeeva, E. (2015). Rol' sotsial'nogo statusa kommunikantov v vyrazhenii menasivnoŭ i avertivnoŭ semantiki (na primere frantsuzskogo diskursa). Politicheskaia lingvistika, 2015(1), 164-168.

Evangelie uchitelnoe, albo kazania na kozhduiu nedeliu i sviata urochistyi. (1616). Drukarnia Vīl'nius'kogo bratstva. http://irbis-nbuv.gov.ua/dlib/item/0000067

Gel'fond, M. (2014). K voprosu o sootnoshenii morali i tsivilizatsii. Ėticheskaia mysl', 14, 25-35. 
Haliatovs'kyı̆, I. (1985). Kliuch rozumĕnnia. In I. Haliatovs'kyı̆, Kliuch rozuminnia (pp. 53-211). Naukova dumka. (Original work published 1659).

IEvangelie uchitelnoe, albo kazania na kozhduiu nedīliu i sviata urochistyī. (1637). Drukarnia Kyievo-Pechers'koï lavry. http://irbis-nbuv.gov.ua/dlib/item/0000059

Kintsel', A. (2013). Psikholingvisticheskie mekhanizmy rechevogo vozdeřstviia. Izvestiia Altaĭskogo gosudarstvennogo universiteta, 2(2), 150-154. https://doi.org/10.14258 /izvasu(2013)2.2-33

Klenina, I. (2003). Preventiv: Semantika i sposoby vyrazheniia [Unpublished doctoral dissertation]. Riazanskiı̌ gosudarstvennyı̌ universitet imeni S. A. Esenina.

Kovalev, G. (1987). Tri paradigmy v psikhologii - tri strategii psikhologicheskogo vozdeřstviia. Voprosy psikhologii, 1987(3), 41-49.

Kuravs'ka, N. (2016). Semantyka prokhibityva ta zasoby hoho vyrazhennia v suchasniŭ ukraïns'kiĭ movi. Aktual'ni problemy filolohii ta perekladoznavstva, 10(2), 70-74.

Leont'ev, A. (1997). Psikhologiia obshcheniia. Smysl.

Mechkovskaia, N. B. (1998). IAzyk i religiia. Agentstvo "FAIR".

Nazari, F. (2011). Sposoby vyrazheniia zapreta v russkom iazyke. Vestnik Nizhegorodskogo universiteta im. N. I. Lobachevskogo, 2011(6), 684-686.

Paslavs'ka, A. (2010). Movlennievyǐ zhanr “zapovid'” v aspekti mizhkul'turnoï komunikatsii. In R. Pomirko, F. Batsevych, \& A. Paslavs'ka, Movlennievi zhanry v mizhkul'turniı̆ komunikatsii (pp. 63-82). PAiS.

Radyvylovs'kyı̆, A. (1676). Ogorodok Marīi Bogoroditsȳ. Drukarnia Kyievo-Pechers'koï lavry. http://irbis-nbuv.gov.ua/dlib/item/0000123

Radyvylovs'kyı̆, A. (1688). Venets Khristov. Drukarnia Kyievo-Pechers'koï lavry. http://irbis-nbuv .gov.ua/dlib/item/0000071

Saveliuk, N. (2015). Psikhologicheskie osobennosti osnovnykh zhanrov religioznogo diskursa: molitvy, ispovedi, propovedi i obriadovogo derstviia. Science and Education: A New Dimension: Pedagogy and Psychology, 3(30/59), 78-81.

Semia slova Bozhīia. (1772). Drukarnia Uspens'koho monastyria. http://irbis-nbuv.gov.ua /dlib/item/0000015

Sternin, I. (2015). Osnovy rechevogo vozdeǐstviia. Direkt Media.

Voĭtsekhivs'ka, N. (2014). Zasoby vyrazhennia pohrozy v ukraïns'komu konfliktnomu dialohichnomu dyskursi. Humanitarna osvita $v$ tekhnichnykh vyshchykh navchal'nykh zakladakh, 2014(30), 17-30.

Zelins'ka, O. I. (2013). Barokova propovid' iak vidobrazhennia ukraïns'ko-pol's'kykh zv’iazkiv. In R. Dymczyk, I. Krywoszeja, \& N. Morawiec (Eds.), Polsko-ukraiński dyskurs humanistyczny (pp. 275-281). Wydawnictwo "Taurus".

Zvezdin, D. (2011). Pravoslavnaia propoved' kak kommunikativnyı̌ akt (na primere tvorchestva arkhimandrita Ioanna Krest'iankina). Vestnik Cheliabinskogo gosudarstvennogo universiteta, 2011(33): Filologiia; Iskusstvovedenie, 60, 52-54. 


\section{Warnings and Prohibitions as Means of Exerting Influence on the Addressee in Seventeenth- Eighteenth-Century Ukrainian Sermons}

\section{Summary}

In religious communication, psychological influence - as a result of which a person should change their subjective features (value orientations, ways of conduct, etc.) - is aimed at fostering compliance with religious norms The tasks of a priest include religious education and correcting people's behaviour, warning them against acts which contradict Christian values, in other words: preventing people from committing sins. This task is best achieved by means of verbal persuasion used in sermons.

This paper offers a diachronic analysis of speech acts of warning and prohibition (preventives and prohibitives) on the basis of written monuments of the Ukrainian language: Ukrainian sermons from the seventeenth and eighteenth centuries. In the analysed sermons, they are used in order to achieve the aim of preventing sinful conduct. They refer both to everyday situations and to moral attitudes in general.

In the texts under consideration, the semantics of warning and prohibition is conveyed using means of expression from different levels. At the lexical level, they are verbs with the general meaning 'to warn', 'to be afraid', and verbs of action creating a distance between the individual and sinful feelings, thoughts and actions: 'to escape', 'to reject'. Words and phrases denoting cognitive processes play the role of discourse markers: 'to know', 'to be aware of', 'to remind'.

The speech acts of warning and prohibition are most frequently expressed with verbs in the form of negative imperative. One specific aspect of the use of preventives is that they are supplemented with recommendations which the addressee may accept of his/her own will.

The preacher uses various rhetorical strategies to enhance the convincing function of warnings, such as references to widely known cases from the past (precedential phenomena), quotations from the Holy Scripture, and preventive exhortations. In order to better convince the congregation and urge them 
to follow the model of proper conduct, the preacher uses various means of expression: epithets conveying negative valuation, and stylistic figures: amplification, gradation, pairs of synonyms.

The material under consideration makes it possible to conclude that the Ukrainian language of the seventeenth-eighteenth centuries had a considerable potential in terms of verbal persuasion, and opens prospects for the study of its dynamics.

\section{Ostrzeżenia i zakazy jako środki wywierania wpływu na adresata w XVII-XVIII-wiecznych kazaniach ukraińskich}

\section{Streszczenie}

W komunikacji religijnej psychologiczne oddziaływanie na osobę nastawione na zmianę subiektywnych cech (wyznawanych wartości, zachowania itp.) ma na celu propagowanie życia w zgodzie z normami religijnymi. Do zadań kapłana należy wychowanie i poprawa ludzkich zachowań, ostrzeganie przed czynami i działaniami sprzecznymi z wartościami chrześcijańskimi, a więc zapobieganie grzechowi. Najskuteczniejszym środkiem realizacji tego celu w działalności homiletycznej jest zastosowanie perswazji słownej.

Niniejszy artykuł przedstawia analizę diachroniczną dwóch typów aktów mowy o charakterze dyrektywnym: ostrzeżeń i zakazów (prewentywów i prohibitywów), przeprowadzoną na materiale zabytków piśmiennictwa ukraińskiego - XVII-XVIII-wiecznych kazaniach ukraińskich. W analizowanych kazaniach środki te odnoszą się zarówno do sytuacji życia codziennego, jak i ogólnych postaw moralnych, a ich zastosowanie ma na celu zapobieganie grzesznemu zachowaniu.

W badanych tekstach semantyka zakazu i ostrzeżenia jest wyrażana na różnych poziomach. Na poziomie słownictwa są to czasowniki o ogólnym znaczeniu 'ostrzegać', 'bać się', a także czasowniki oznaczające działania wprowadzające dystans pomiędzy adresatem a grzesznymi uczuciami, myślami i działaniami: 'uciekać', 'odrzucać. Rolę znaczników dyskursu pełnią słowa i frazy oznaczające procesy kognitywne: 'znać, 'wiedzieć, 'przypominać. 
Ostrzeżenia i zakazy są najczęściej wyrażane czasownikami w formie przeczącej trybu rozkazującego. Jednym ze szczególnych aspektów ich zastosowania jest to, że są one uzupełniane zaleceniami, które adresat może zaakceptować z własnej woli.

Kaznodzieja stosuje różne strategie retoryczne, żeby wzmocnić perswazyjną funkcję ostrzeżeń. Należą do nich odwołania do znanych zjawisk (zjawisk precedensowych), cytaty z Pisma Świętego czy zapobiegawcze zaklinania. Aby lepiej przekonać wiernych i nakłonić ich do przestrzegania modelu właściwego zachowania, stosuje różne środki wyrazu: epitety wyrażające negatywną ocenę, jak również figury stylistyczne: amplifikację, gradację czy pary synonimów.

Badany materiał skłania do wniosku, że język ukraiński XVII-XVIII wieku miał znaczny potencjał w zakresie perswazji słownej i otwiera perspektywy badań nad dynamiką jej rozwoju.

Keywords: sermon; verbal persuasion; speech act of warning and prohibition; preventive; prohibitive; imperative; Ukrainian language of the 17th-18th centuries

Słowa kluczowe: kazanie; perswazja słowna; akty mowy: ostrzeżenie i zakaz; prewentyw; prohibityw; tryb rozkazujący; język ukraiński XVII-XVIII wieku

Oksana Zelinska, Pavlo Tychyna Uman State Pedagogical University, Uman, Ukraine

ORCID: https://orcid.org/0000-0002-7965-428X

Correspondence: zelinska67@ukr.net

The preparation of this article was self-financed by the author.

Competing interests: The author has declared that she has no competing interests. 